\title{
PERSEPSI PETANI TERHADAP UPJA \\ (USAHA PELAYANAN JASA ALSINTAN) \\ DI KECAMATAN TAWANGSARI KABUPATEN SUKOHARJO
}

\author{
THE PEASANTS' PERCEPTION TO UPJA \\ (AGRICULTURAL EQURIPMENTS AN MACHINERIES \\ SERVICE BUSINESS) \\ IN TAWANGSARI SUBDISTRICTS SUKOHARJO REGENCY
}

\author{
Listya Gustani Husnayati ${ }^{1}$, Suwarto ${ }^{2}$, Hanifah Ihsaniyati ${ }^{3}$ \\ Agricultural Extension and Communication the Faculty of Agriculture \\ Sebelas Maret University \\ Email: listyagustanihusnayati@gmail.com /No. Hp 082219263888
}

\begin{abstract}
The aim of this research is to know the peasants' perception factors to UPJA, to analyze the peasants' perception to UPJA, to analyze the correlation between the peasants' perception maker with the peasants' perception to UPJA, and to analyze the difference of the peasants' perception to UPJA based on the farmers area and peasants' position in the peasants' group. The basic method used in this research was descriptive quantitative with survey technique. The location of the research was determined by the purposive that was in Tawangsari District Sukoharjo Regency, by taking 2 peasants' group that was Ngudi Rejeki in Dalangan and Ngudi Makmur in Majasto Village. The sample was determined by multistage cluster random sampling technique, as many as 60 farmer's respondents. The data analysis used was rank spearman and $U$ Mann-Whitney. The result of this research indicate that the perception form factor was the age of the farmers in the medium category, formal education in the high category, non-formal education in the low category, experience in the medium category, income in the very high category, wide land in the very broad categories and the economic environment in the medium category. The Peasants' Perception to UPJA that was $61.67 \%$ farmer's respondents had the good perception to UPJA. There was a significant relation between non-formal education and the economic environment with peasants' perception to UPJA at $99 \%$ level of confidence, at $90 \%$ level there was a significant relation between the experience, income and land area with the peasants' perception to UPJA, while the age and formal education there was no significant correlation with the farmers perception to UPJA. There was a significant difference perception to UPJA based on peasants' area and peasants' position in peasants' group.
\end{abstract}

Keywords: Perception Maker Factor;Perception; Rank Spearman; U Mann-Whitney; UPJA.

Abstrak: Penelitian ini bertujuan untuk mengetahui faktor-faktor pembentukpersepsi petani terhadap UPJA, menganalisis persepsi petani terhadap UPJA, menganalisis hubungan antara faktor-faktor pembentuk persepsi dengan persepsi petani terhadap UPJA serta menganalisis perbedaan persepsi petani terhadap UPJA berdasarkan lingkungan petani dan kedudukan petani di kelompok 


\section{Jurnal Agritexts Volume 42 Nomer 1 Mei 2018}

tani. Metode dasar yang digunakan dalam penelitian ini adalah deskriptif kuantitatif dengan teknik survei. Lokasi penelitian ditentukan secara purposive yaitu Kecamatan Tawangsari Kabupaten Sukoharjo, dengan mengambil 2 kelompok tani yaitu kelompok tani Ngudi rejeki di Desa Dalangan dan Ngudi Makmur di Desa Majasto. Sampel ditentukan dengan teknik multi stage cluster random sampling, sebanyak 60 petai responden. Analisis data yang digunakan adalah rank spearman dan U Mann-Whitney. Hasil penelitian menunjukkan bahwa faktor pembentuk persepsi yaitu umur petani dalam kategori sedang, pendidikan formal dalam kategori tinggi, pendidikan non formal dalam kategori rendah, pengalaman dalam kategori sedang, pendapatan dalam kategori sangat tinggi, luas lahan dalam kategori sangat luasdan lingkungan ekonomi dalam kategori sedang. Persepsi petani terhadap UPJA yaitu $61,67 \%$ petani responden berpersepsi baik terhadap UPJA. Terdapat hubungan yang sangat signifikan antara pendidikan non formal dan lingkungan ekonomi dengan persepsi petani terhadap UPJA pada taraf kepercayaan $99 \%$, pada taraf $90 \%$ terdapat hubungan yang signifikan antara pengalaman, pendapatandanluaslahan dengan persepsi petani terhadap UPJA, sedangkan umurdanpendidikan formaltidak terdapat hubungan yang signifikan dengan persepsi petani terhadap UPJA. Terdapat perbedaan persepsi yang signifikan terhadap UPJA berdasarkan lingkungan petani dan kedudukan petani di kelompok tani.

Kata Kunci: Faktor Pembentuk Persepsi;Persepsi;Rank Spearman; U Mann-Whitney; UPJA.

\section{PENDAHULUAN}

Pembangunan pertanian bertujuan untuk mewujudkan kedaulatan pangan Indonesia supaya dapat mengatur dan memenuhi kebutuhan pangan yang dimulai dari swasembada pangan. Upaya pemerintah untuk mewujudkan ketahanan pangan tidak berjalan mulus. Pemerintah menghadapi masalah produktivitas padi yang cenderung stag nanbahkan menurun ditambah mayoritas petani yang bekerja di sawah kurang yang akhirnya berpengaruh pada produktivitas pertanian. Kondisi tersebut menuntun adanya teknologi alat dan mesin pertanian. Strategi pengembang analsintan dalam rangka pemanfaatan inovasi dan teknolog imekanisasi pertanian dengan menumbuh dan mengembangkan system kelembagaan Usaha Pelayanan JasaAlsintan (UPJA). UPJA adalah salahsatu unit usaha KelompokTani (Poktan) atau Gabungan Kelompok Tani (Gapoktan) yang bergerak di bidang pelayanan jasa dalam rangka mengoptimalkan penggunaan alsintan dalam penanganan budidaya dari persiapan hingga pascapanen.

\section{Kementerian Pertanian pada} Tahun 2008 membentuk kelembagaan UPJA percontohan di 13 provinsi. Saatini kelembagaan UPJA sudah berkembang meluas, sehingga pada setia pprovinsi sudah dijumpai kelembagaan UPJA. Kabupaten di provinsiJawa Tengah yang dijadikan percontohan adalah Kabupaten 
Sukoharjo. KecamatanTawangsari merupakan Kecamatan yang berada di Kabupaten Sukoharjo, di mana salahsatu UPJA di Kecamatan Tawangsariyaitu UPJA Bagyo Mulyo yang berada di Desa Dalangan dijadikan sebagai percontohan Nasional. Berdasar kanhasil survei di lapang di Kecamatan Tawangsari terdapat 2 desa yang sudah membentuk UPJA yaitu Desa Dalangan dan Desa Majastro. UPJA di Desa Dalangan terbentuk pada Tahun 2014 dan saat ini sudah dijadikan percontohan Nasional. UPJA di Desa Majastro terbentuk Tahun 2016 sampai saat ini belum berkembang. Keberhasilan dan keberlanjutan suatu program tidak terlepas dari pandangan atau persepsi orang (petani) terhadap suatu program atau kelembagaan, yang kaitannya dengan penilaian baik, buruk, keuntungan, kerugian serta manfaat program atau kelembagaan tersebut. Hal tersebut yang mendasari peneliti untuk meneliti bagaimana Persepsi Petani terhadap Usaha Pelayana nJasa Alsintan (UPJA) Di Kecamatan Tawangsari Kabupaten Sukoharjo.

Berdasarkan uraian di atas, maka tujuan penelitian ini adalah sebagai berikut : (1) Mengidentifikasi faktor-faktor pembentuk persepsi petani terhadap UPJA (Usaha PelayananJasaAlsintan) Di Kecamatan Tawangsari Kabupaten Sukoharjo. (2) Menganalisis persepsi petani terhadap UPJA (Usaha Pelayanan Jasa Alsintan) Di Kecamatan TawangsariK abupaten Sukoharjo. (3) Menganalisis hubungan antara faktor-faktor pembentuk persepsi dengan persepsi petani terhadap UPJA (Usaha Pelayanan Jasa Alsintan) Di Kecamatan Tawangsari Kabupaten Sukoharjo. (4) Menganalisis perbedaan persepsi petani terhadap UPJA (Usaha Pelayanan Jasa Alsintan) Di Kecamatan Tawangsari Kabupaten Sukoharjo berdasarkan:

Lingkunga npetani yaitu jarak akses jauh dari Kantor Kecamatandan BPP dengan jarak akses dekat dengan Kantor Kecamatan dan BPP (b) Kedudukan petani pada kelompok tani yaitu pengurusdan anggota.

\section{METODE PENELITIAN}

Metode dasar yang digunakan dalam penelitian ini adalah deskriptif kuantitatif, sedangkan teknik yang digunakan adalah teknik survei. Pemilihan lokasi penelitian dilakukan secara purposive yang didasarkan karena Kecamatan Tawangsari Kabupaten Sukoharjo memiliki lahan pertanian yang luas dan kelembagaan UPJA (Usaha Pelayanan Jasa Alsintan) di salah satu Desanya telah dijadikan sebagai percontohan Nasional oleh Kementerian Pertanian. Populasi dalam penelitian ini adalah petani yang tergabung dalam kelembagaan UPJA di Kecamatan Tawangsari Kabupaten Sukoharjo. 


\section{Jurnal Agritexts Volume 42 Nomer 1 Mei 2018}

Pengambilan Sampel dilakukan dengan menggunakan teknik multi stage cluster random sampling yaitu teknik dengan model pengelompokan secara bertahap (dua atau lebih) dengan mengelompokan unit analisa ke dalam gugus dimana sampel akan diambil, melalui tahaptahap tertentu (Singarimbun, dan M, Effendi, 1989). Penarikan sampel dilakukan secara acak dengan melalui kelompok pembagian cluster terendah terlebih dahulu. Responden dipilih menggunakan teknik acak (random) dimana pada masingmasing kelompok tani akan diacak sedemikian rupa sehingga setiap populasi akan mempunyai kemungkinan yang sama. Jenis dan sumber data yang digunakan dalam penelitian ini adalah data primer dan data sekunder. Teknik pengumpulan data yang digunakan dalam penelitian ini adalah observasi, wawancara dan pencatatan. Penelitian ini menggunakan uji korelasi rank spearman dan uji U mann-whitney.

\section{HASIL DAN PEMBAHASAN}

Menurut data Kecamatan Tawangsari dalam Angka Tahun 2016, Kecamatan Tawangsari merupakan salah satu Kecamatan di Kabupaten Sukoharjo. Kecamatan tawangsari memiliki luas wilayah $39,98 \mathrm{~km}^{2}$ atau $8,57 \%$ dari luas Kabupaten Sukoharjo (46.666 Ha). Luas yang ada terdiri dari $1.674 \mathrm{Ha}$ atau $41,87 \%$ lahan sawah dan 2.324 $\mathrm{Ha}$ atau 53,13\% bukan lahan sawah. Luas bukan lahan sawah yang digunakan untuk pekarangan sebesar $54 \%$ dari total lahan bukan lahan sawah. Jumlah penduduk Tahun 2015 yaitu 59.750 jiwa, terdiri dari 29.556 laki-laki dan 30.194 perempuan. Angka Beban Tanggungan (ABT) sebanyak 49, yang berarti bahwa setiap 100 jiwa penduduk usia produktif menanggung 49 jiwa penduduk usia non produktif.

Kondisi penduduk di Kecamatan Tawangsari yang memiliki persentase tertinggi berusaha di sektor pertanian dan menjadikan sektor pertanian sebagai lapangan pekerjaan utama. Namun, ketenagakerjaan dibidang pertanian semakin sulit sehingga petani kesulitan dalam usahatani dan mengakibatkan hasil usahataninya tidak maksimal. Oleh karena itu perlu adanya teknologi pertanian yang mampu meningkatkan pendapatan keluarga petani.

TerkaitdenganUsaha Pelayanan Jasa Alsintan (UPJA) merupakan suatu lembaga ekonomi perdesaan yang bergerak di bidang pelayanan jasa dalam rangka optimalisasi penggunaan alsintan dari persiapan hingga pascapanen untuk mendapatkan keuntungan usaha. Upaya pemerintah untuk mempercepat perkembangan UPJA secara rutin melakukan pembinaan, monitoring dan evaluasi kepada kelompok UPJA 


\section{Husnayati, Suwarto, Ihsaniyati, Faktor Pembentuk,נ,}

supaya kemampuan dan ketrampilan pengelola UPJA meningkat. Kelembagaan UPJA di Kecamatan Tawangsari saat ini berada di 2 Desa yaitu Desa Dalangan dan Desa Majasto. UPJA di Desa Dalangan yang bernama UPJA Bagyo Mulyo terbentuk pada Tahun 2014 dan saat ini sudah dijadikan percontohan Nasional .UPJA di Desa Majasto yang bernama Sumber Rejeki terbentuk pada Tahun 2016 sampai saat ini belum berkembang karena terhambat oleh faktor modal dan informasi terkait UPJA. Struktur kepengurusan UPJA Bagyo Mulyo terdiri dari manajer, sekretaris dan bendahara, operator, perbengkelan dan pemasaran serta didukung oleh teknisi, sedangkan struktur kepengurusan di UPJA Sumber Rejeki baru terbentuk ketua, bendahara, sekretaris dan operator.UPJA Bagyo Mulyo menurut Manajer UPJAmenerangkan telah mempunyai pompa air sebanyak 3 unit, traktor roda dua sebanyak 1 unit, traktor roda empat sebanyak 2unit, Rice transpanter sebanyak 3 unit, Combine Harvester sebanyak 2 unit, Peralatan bengkel sebanyak lunit, sepeda motor roda tiga sebanyak 2 unit dan Tray sebanyak 771 buah. Kondisi ini sudahber kembang karena awal berdirinya UPJA aset awal yang dimiliki yaitu traktor roda dua 1 unit, pompa air sebanyak 3 unit dan combine harvester sebanyak 1 unit. UPJA Sumber Rejeki hingga saat ini baru memiliki Rice transpanter sebanyak 1 unit, Traktor roda dua sebanyak 1 unit, pompa air sebanyak 1 unit dan tray sebanyak 50 buah.

Harga sewa alsintan dalam usahatani padi dalam setiap 1 (satu) $\mathrm{Ha}$ di Kecamatan Tawangsari berbeda-beda. Begitu pula dengan biaya tenaga dalam setiap tahapan dalam usahatani. Harga sewa traktor sebesar Rp 1.000.000,00; Transplanter sebesar $\mathrm{Rp} 3.000 .000,00$ dan Combine Harvester Rp 2.000.000,00. Biaya yang dibayarkan untuk tenaga kerja pada masa tanam sebesar Rp 1.000.000,00; penyiangan Rp 960 . 000,00; pemupukan Rp 1.200.000,00 dan biaya untuk panen sebesar $\mathrm{Rp}$ $5.300 .000,00$.

\section{Faktor-faktor Pembentuk Persepsi}

Rakhmat (2003) mengartikan persepsi sebagai pengalaman belajar tentang objek, peristiwa atau hubungan-hubungan yang diperoleh dengan menyimpulkan informasi dan menafsirkan pesan. Persepsi juga merupakan suatu bentuk komunikasi intrapersonal yaitu komunikasi yang terjadi dalam diri seseorang. Oleh karena itu, persepsi akan mempengaruhi seseorang dalam berpikir, bertindak, serta berkomunikasi dengan pihak lain. 
Jurnal Agritexts Volume 42 Nomer 1 Mei 2018

Tabel 1.Faktor-FaktorPembentukPersepsi

\begin{tabular}{|c|c|c|c|c|c|}
\hline No. & Faktor-faktor & Skor & Kategori & Jumlah & Persentase (\%) \\
\hline \multirow[t]{5}{*}{1.} & Umur & 1 & Sangatrendah & 6 & 10,00 \\
\hline & & 2 & Rendah & 16 & 26,67 \\
\hline & & 3 & Sedang & 25 & 41,67 \\
\hline & & 4 & Tinggi & 12 & 20,00 \\
\hline & & 5 & Sangattinggi & 1 & 1,66 \\
\hline \multirow[t]{5}{*}{2.} & Pendidikan Formal & 1 & Sangatrendah & 5 & 8,33 \\
\hline & & 2 & Rendah & 13 & 21,67 \\
\hline & & 3 & Sedang & 12 & 20,00 \\
\hline & & 4 & Tinggi & 26 & 43,33 \\
\hline & & 5 & Sangattinggi & 4 & 6,67 \\
\hline \multirow[t]{5}{*}{3.} & Pendidikan Non Formal & 6-10 & Sangatrendah & 21 & 35,00 \\
\hline & & $11-15$ & Rendah & 8 & 13,33 \\
\hline & & $16-20$ & Sedang & 18 & 30,00 \\
\hline & & 21-25 & Tinggi & 13 & 2,67 \\
\hline & & $26-30$ & Sangattinggi & 0 & 0,00 \\
\hline \multirow[t]{5}{*}{4.} & Pengalaman & $4-7$ & Sangatrendah & 12 & 20,00 \\
\hline & & $8-10$ & Rendah & 15 & 25,00 \\
\hline & & $11-13$ & Sedang & 24 & 40,00 \\
\hline & & $14-16$ & Tinggi & 9 & 15,00 \\
\hline & & $17-20$ & Sangattinggi & 0 & 0,00 \\
\hline \multirow[t]{5}{*}{5.} & Pendapatan & 1 & Sangatrendah & 1 & 1,67 \\
\hline & & 2 & Rendah & 9 & 15,00 \\
\hline & & 3 & Sedang & 8 & 13,33 \\
\hline & & 4 & Tinggi & 6 & 10,00 \\
\hline & & 5 & Sangattinggi & 36 & 60,00 \\
\hline \multirow[t]{5}{*}{6.} & Luas Lahan & 1 & Sangatsempit & 2 & 3,33 \\
\hline & & 2 & Sempit & 6 & 10,00 \\
\hline & & 3 & Sedang & 17 & 28,33 \\
\hline & & 4 & Luas & 16 & 26,67 \\
\hline & & 5 & Sangatluas & 19 & 31,67 \\
\hline \multirow[t]{5}{*}{7.} & LingkunganEkonomi & $4-7$ & Sangatrendah & 6 & 10,00 \\
\hline & & $8-10$ & Rendah & 12 & 20,00 \\
\hline & & $11-13$ & Sedang & 24 & 40,00 \\
\hline & & $14-16$ & Tinggi & 7 & 1,67 \\
\hline & & $17-20$ & Sangattinggi & 11 & 18,33 \\
\hline
\end{tabular}

Sumber: Analisis Data Primer Tahun 2017

BerdasarkanTabel 1 menunjukkan bahwaumur responden termasuk dalam kategori umur produktif dengan persentase $41,67 \%$. Pendidikan formal responden termasuk dalam kategori tinggi (SMA) dengan persentase 43,33 \%.Pendidikan non formal termasuk dalam kategori sangat rendah dengan persentase sebesar $35 \%$.Pengalaman responden termasuk dalam kategori sedang dengan persentase $40 \%$.Pendapatan responden termasuk dalam kategori sangat tinggi dengan persentase 60 $\%$.Luas lahan responden termasuk dalam kategori sangat luas dengan persentase 31,67.Lingkungan ekonomi responden berada dalam kategori sedang dengan persentase $40,00 \%$. 
Husnayati, Suwarto, Ihsaniyati, Faktor Pembentuk,,

Persepsi Petani terhadap Usaha Pelayanan Jasa Alsintan (UPJA) di Kecamatan Tawangsari Kabupaten Sukoharjo

Tabel 2. Distribusi Responden Berdasarkan Tingkat Persepsi petani terhadap UPJA (Usaha Pelayanan Jasa Alsintan)

\begin{tabular}{|c|c|c|c|c|c|}
\hline No. & Uraian & Kategori & Skor & Jumlah & Persentase (\%) \\
\hline \multirow[t]{5}{*}{1.} & Persepsi terhadap & Sangat Buruk & $11-19$ & 0 & 0,00 \\
\hline & Pengertian UPJA & Buruk & $20-28$ & 3 & 5,00 \\
\hline & (Y1) & Cukup Baik & $29-37$ & 13 & 21,67 \\
\hline & & Baik & $38-46$ & 32 & 53,33 \\
\hline & & Sangat Baik & $47-55$ & 12 & 20,00 \\
\hline \multirow[t]{5}{*}{2.} & Persepsi terhadap & Sangat Buruk & $11-19$ & 0 & 0,00 \\
\hline & Manfaat UPJA & Buruk & $20-28$ & 3 & 5,00 \\
\hline & $(\mathrm{Y} 2)$ & Cukup Baik & $29-37$ & 13 & 21,67 \\
\hline & & Baik & $38-46$ & 35 & 58,33 \\
\hline & & Sangat Baik & $47-55$ & 9 & 15,00 \\
\hline \multirow[t]{10}{*}{3.} & Persepsi terhadap & Sangat Buruk & $33-58$ & 0 & 0,00 \\
\hline & Kegiatan UPJA & Buruk & $59-84$ & 2 & 3,33 \\
\hline & (Y3) & Cukup Baik & $85-110$ & 11 & 18,34 \\
\hline & & Baik & $111-136$ & 35 & 58,33 \\
\hline & & Sangat Baik & $137-165$ & 12 & 20,00 \\
\hline & Persepsi petani & Sangat Buruk & $55-98$ & 0 & 0,00 \\
\hline & terhadap UPJA & Buruk & $99-142$ & 1 & 1,67 \\
\hline & (Ytot) & Cukup Baik & $143-186$ & 12 & 20,00 \\
\hline & & Baik & $187-230$ & 37 & 61,67 \\
\hline & & Sangat Baik & $231-275$ & 10 & 16,66 \\
\hline
\end{tabular}

Sumber: Analisis Data Primer 2017

Berdasarkan Tabel 2 dapat diketahui bahwa persepsi petani terhadap pengertian UPJA di Kecamatan Tawangsari yang memiliki persentase terbesar tergolong dalam kategori sangat baik sebanyak 32 orang atau sebesar 53,33 \%. Hasil tersebut menunjukkan bahwa tingkat persepsi petani terhadap pengertian UPJA di Kecamatan Tawangsari dikategorikan baik. Penilaian petani terhadap pengertian UPJA dari segi pemahaman UPJA, instansi penyelenggara dan pelaksana UPJA baik.
Tujuan UPJA sesuai dengan kebutuhan petani yaitu memudahkan dan mempercepat usahatani dari persiapan hingga pasca panen serta meningkatkan pendapatan petani.

Berdasarkan Tabel 2 dapat diketahui bahwa persepsi petani terhadap manfaat UPJA di Kecamatan Tawangsari yang memiliki persentase terbesar tergolong dalam kategori baik sebanyak 35 orang atau sebesar 58,33 \%. Hasil tersebut menunjukkan bahwa tingkat persepsi petani terhadap manfaat UPJA di 
Kecamatan Tawangsari dikategorikan baik. Persepsi petani terhadap UPJA yang baik dapat meningkatkan manfaat bagi petani sendiri karena UPJA yang ada memberikan nilai-nilai positif bagi petani, misalnya pendapatan petani meningkat, biaya yang dikeluarkan untuk usahatani menurun, waktu yang diperlukan untuk usahatani lebih singkat dan tenaga yang diperlukan untuk usahatani lebih sedikit.

Berdasarkan Tabel 2 dapat diketahui bahwa persepsi petani terhadap kegiatan UPJA di Kecamatan Tawangsari yang memiliki persentase tergolong dalam kategori baik sebanyak 35 orang atau sebesar 58,33 \%. Hasil tersebut menunjukkan bahwa tingkat persepsi petani terhadap kegiatan UPJA di Kecamatan Tawangsari dikategorikan baik. Ke- giatan yang dilakukan dalam UPJA yaitu sosialisai UPJA, pendataan UPJA, musyawarah kelompok dan pelatihan.

Berdasarkan Tabel 2 dapat diketahui bahwa persepsi petani terhadap UPJA di Kecamatan Tawangsari yang memiliki persentase tertinggi tergolong dalam kategori baik sebanyak 37 orang atau 61,67\%. Responden dalam kategori sangat baik sejumlah 10 orang atau sebesar $16,66 \%$, sedangkan yang memiliki persentase terendah tergolong dalam kategori buruk terhadap UPJA sebanyak 10 orang atau sebesar $1,67 \%$. Berdasarkan data tersebut, maka dapat disimpulkan bahwa persepsi petani terhadap UPJA di Kecamatan Tawangsari dikategorikan baik.

Hubungan antara faktor-faktor pembentuk persepsi dengan persepsi petani terhadap UPJA (Usaha Pelayanan Jasa Alsintan) di Kecamatan Tawangsari Kabupaten Sukoharjo

Tabel 3. Hubungan antara Faktor-Faktor Pembentuk Persepsi Dengan Persepsi Petani terhadap UPJA

\begin{tabular}{lcr}
\hline \multicolumn{1}{c}{$\begin{array}{c}\text { Faktor pembentuk persepsi } \\
\text { (X) }\end{array}$} & \multicolumn{2}{c}{ Persepsi Total (Y) } \\
\cline { 2 - 3 }$($ X1) Umur & \multicolumn{1}{c}{$\mathrm{r}_{\mathrm{s}}$} & \multicolumn{1}{c}{ Sig. (2-tailed) } \\
(X2) Pendidikan Formal & 0.126 & 0.339 \\
(X3) Pendidikan Non Formal & 0.144 & 0.273 \\
(X4) Pengalaman & $0.489^{* *}$ & 1.108 \\
(X5) Pendapatan & $0.254^{*}$ & 0.000 \\
(X6) Luas Lahan & $0.226^{*}$ & 0.050 \\
(X7) Lingkungan Ekonomi & $0.216^{*}$ & 0.082 \\
\hline
\end{tabular}

Sumber: Analisis Data Primer Tahun 2017

Keterangan:

$r_{s} \quad$ : Korelasi Rank Spearman

** : signifikan pada $\alpha=0,01$

hit : : thitung

* : signifikan pada $\alpha=0,05$ 


\section{Husnayati, Suwarto, Ihsaniyati, Faktor Pembentuk,נ,}

Sig. (2-tailed) : $p$ value

t tabel : 2,680 $(\alpha=0,01)$ taraf kepercayaan 99\%

t tabel : 2,009 $(\alpha=0,05)$ taraf kepercayaan 95\%
* : signifikan pada $\alpha=0,10$

t tabel : 1,676 $(\alpha=0,10)$ taraf

kepercayaan $90 \%$
Hubungan antara umur dengan persepsi petani terhadap UPJA

Berdasarkan Tabel 3 dapat diketahui bahwa nilai koefisien korelasi ( $r s$ ) sebesar $0.126, p$ value sebesar 0,339 dengan $t$ hitung sebesar 0,967 dan $t$ tabel sebesar 2,011, sehingga dapat diketahui bahwa t hitung $<\mathrm{t}$ tabel pada taraf signifikansi $95 \%$ maka HO diterima dan H1 ditolak, yang artinya tidak terdapat hubungan yang signifikan antara umur dengan persepsi petani terhadap UPJA. Hal ini menunjukkan bahwa perbedaan tingkat umur dan bertambahnya umur petani tidak berhubungan dengan persepsi petani terhadap UPJA. Hasil penelitian ini tidak sesuai dengan pernyataan As'sad (1995) dan Hernanto (1984) bahwa faktor personal yang mempengaruhi persepsi adalah umur, umur diantara 25-34 tahun dan 40-45 tahun adalah merupakan umur yang bisa menimbulkan persepsi puas terhadap suatu pekerjaan. Umur akan mempengaruhi kemampuan fisik dan respon terhadap halhal baru dalam menjalankan usahatani.

Hubungan yang tidak signifikan antara umur dengan persepsi petani terhadap UPJA menunjukkan bahwa persepsi petani tidak berhubungan dengan tingkat umur petani. Bertambahnya usia petani tidak berhubungan baik maupun buruk dengan persepsi petani terhadap UPJA. Usia petani baik yang produktif maupun non produktif berperan aktif dalam UPJA dan mempunyai kesempatan yang sama.

Hubungan antara pendidikan formal dengan persepsi petani terhadap UPJA

Berdasarkan Tabel 3 dapat diketahui bahwa nilai koefisien korelasi ( $r$ s) sebesar $0,144, p$ value sebesar 0,273 , dengan $t$ hitung sebesar 1,108 dan $t$ tabel sebesar 2,011, sehingga dapat diketahui bahwa t hitung $<\mathrm{t}$ tabel pada taraf signifikansi 95\% maka HO diterima dan $\mathrm{H} 1$ ditolak, yang artinya tidak terdapat hubungan yang signifikan antara pendidikan formal dengan persepsi petani terhadap UPJA. Hal ini menunjukkan bahwa perbedaan tingkat pendidikan formal petani tidak berhubungan dengan persepsi petani terhadap UPJA. Hasil penelitian ini tidak mendukung pendapat Rakhmat (2005) bahwa perbedaan tingkat pendidikan akan menghasilkan persepsi yang berbeda pula pada suatu obyek atau peristiwa. Perbedaan pengelompokan terhadap obyek yang dipersepsi timbul akibat 


\section{Jurnal Agritexts Volume 42 Nomer 1 Mei 2018}

perbedaan tingkat pendidikan individu. Tingkat pendidikan petani akan mempengaruhi cara berfikir yang diterapkan dalam usahataninya.

Hubungan yang tidak signifikan antara pendidikan formal dengan persepsi petani terhadap UPJA menunjukkan bahwa persepsi petani tidak berhubungan dengan tingkat pendidikan formal petani. Semakin tinggi atau rendahnya tingkat pendidikan petani tidak berhubungan baik maupun buruk dengan persepsi petani terhadap UPJA. Tidak terdapatnya hubungan antara pendidikan formal dengan persepsi petani terhadap UPJA disebabkan karena pengetahuan tentang UPJA tidak diperoleh dari hasil pendidikan formal. Responden memperoleh informasi terkait UPJA dari kegiatan non formal yaitu kegiatan seperti penyuluhan dan pelatihan.

Hubungan antara pendidikan non formal dengan persepsi petani terhadap UPJA

Berdasarkan Tabel 3 dapat diketahui bahwa nilai koefisien korelasi (rs) sebesar 0,489**, p value sebesar 0,000, dengan $t$ hitung sebesar 4,269 dan $t$ tabel sebesar 2,685, sehingga dapat diketahui bahwa t hitung $>\mathrm{t}$ tabel pada taraf signifikansi 99\% maka $\mathrm{HO}$ ditolak dan H1 diterima, yang artinya terdapat hubungan yang sangat signifikan antara pendidikan formal dengan persepsi petani terhadap UPJA. Hal ini menunjukkan bahwa perbedaan tingkat pendidikan formal dan bertambahnya pendidikan formal yang diikuti petani berhubungan dengan persepsi petani terhadap UPJA.

Hubungan yang sangat signifykan antarapendidikan non formal dengan persepsi petani terhadap UPJA menunjukkan bahwa persepsi petani sangat berhubungan dengan tingkatpendidikan non formal petani, semakin banyak petani mengikuti kegiatanpenyuluhan, sosialisasi dan pelatihan maka akan semakin baik pula persepsipetani terhadap UPJA. Hasil penelitian mendukung pernyataan Mulyana (2002) dan Hernanto (1984) yang menyatakan bahwa tingkat pendidikan seseorang merupakan faktor internal yang mempengaruhi atensi, semakin besar perbedaan aspek-aspek internal maka semakin besar perbedaan persepsi mereka mengenai realita. Tingkat pendidikan petani baik formal maupun pendidikan non formal akan mempengaruhi cara berpikir yang diterapkan pada usahataninya.

Hubungan antara pengalaman dengan persepsi petani terhadap UPJA

Berdasarkan Tabel 3 dapat diketahui bahwa nilai koefisien korelasi ( $r s$ ) sebesar 0,254*, p value sebesar 0,050, dengan $t$ hitung sebesar 2.000 dan $t$ tabel sebesar 1,676, sehingga dapat diketahui 


\section{Husnayati, Suwarto, Ihsaniyati, Faktor Pembentuk,נ,}

bahwa $\mathrm{t}$ hitung $>\mathrm{t}$ tabel pada taraf signifikansi $90 \%$ maka HO ditolak dan H1 diterima yang artinya terdapat hubungan yang signifikan antara pengalaman dengan persepsi petani terhadap UPJA. Hal ini menunjukkan bahwa perbedaan pengalaman petani dalam berusahatani berhubungan dengan persepsi petani terhadap UPJA.Hasil penelitian ini sesuai dengan pernyataan Rakhmat (2005) dan Soekartawi (1988) menyatakan bahwa pengalaman mempengaruhi kecermatan persepsi. Pengalaman tidak selalu lewat proses belajar formal. Pengalaman bertambah juga melalui rangkaian peristiwa yang pernah kita hadapi. Petani yang sudah lama berusahatani akan lebih mudah menerapkan teknologi dari pada petani pemula. Hal ini dikarenakan pengalaman yang lebih banyak dapat membuat perbandingan dalam mengambil keputusan.

Pengalaman petani bertambah melalui beberapa peristiwa yang telah dilalui dan dialami petani dalam melakukan usahataninya. Pengalaman petani terdapat hubungan yang signifikan dengan persepsi petani terhadap UPJA, menandakan bahwa keberagaman pengalaman petani dalam berusahatani akan berhubungan terhadap penilaian dan pemahaman terkait UPJA sehingga membentuk persepsi yang berbeda. Petani responden di Kecamatan Tawangsari sudah cukup banyak yang memiliki pengalaman dalam pemanfaatan UPJA meskipun UPJA masih termasuk inovasi baru. Hal ini disebabkan petani responden merasakan manfaat dari inovasi tersebut sehingga petani lain tertarik untuk mengadopsi inovasi tersebut juga.

Hubungan antara pendapatan dengan persepsi petani terhadap UPJA

Berdasarkan Tabel 3 dapat diketahui bahwa nilai koefisien korelasi ( $r s$ ) sebesar $0,226^{*}, \mathrm{p}$ value sebesar 0,082, dengan $t$ hitung sebesar 1,767 dan $t$ tabel sebesar 1,6776, sehingga dapat diketahui bahwa $\mathrm{t}$ hitung $>\mathrm{t}$ tabel pada taraf signifikansi $90 \%$ maka HO ditolak dan H1 diterima, yang artinya terdapat hubungan yang signifikan antara pendapatan dengan persepsi petani terhadap UPJA. Hal ini menunjukkan bahwa perbedaan pendapatan petani berhubungan dengan persepsi petani terhadap UPJA. Hubungan yang signifikan antara pendapatan petani dengan persepsi petani terhadap UPJA menunjukkan bahwa persepsi petani berhubungan dengan tingkat pendapatan petani, sehingga tinggi rendahnya tingkat pendapatan petani berhubungan dengan baik, buruk persepsi petani terhadap UPJA.

Hasil penelitian ini sesuai dengan pernyataan Mulyana (2005) bahwa tingkat pendapatan (ekonomi) mempengaruhi persepsi 


\section{Jurnal Agritexts Volume 42 Nomer 1 Mei 2018}

seseorang terhadap suatu realitas. Semakin besar perbedaan pendapatan antara dua orang, maka semakin besar pula perbedaan persepsi seseorang terhadap realitas. Petani dengan tingkat pendapatan yang tinggi ada hubungannya dengan penggunaan inovasi. Petani dengan pendapatan tinggi akan lebih mudah melakukan sesuatu yang diinginkan sehingga akan lebih efektif dalam partisipasi.

Tinggi rendahnya pendapatan petani berpengaruh dengan persepsi petani terhadap UPJA. Artinya tingkat pendapatan petani dapat merubah persepsi petani terhadap UPJA. Hasil penelitian menunjukkan bahwa pendapatan petani di Kecamatan Tawangsari dalam kategori sangat tinggi, Petani yang memiliki pendapatan tinggi menganggap harga sewa alsintan murah dan memiliki kemampuan untuk memanfaatkan kelembagaan UPJA yang lebih banyak sehingga petani responden memiliki persepsi yang baik terhadap manfaat yang dirasakan petani responden dibandingkan dengan petani responden yang memiliki pendapatan rendah.

Hubungan antara luas lahan dengan persepsi petani terhadap UPJA

Berdasarkan Tabel 3 dapat diketahui bahwa nilai koefisien korelasi ( $r$ ) sebesar 0,216*, p value sebesar 0,097, dengan $t$ hitung sebesar 1,685 dan $t$ tabel sebesar
1,676, sehingga dapat diketahui bahwa $\mathrm{t}$ hitung $>\mathrm{t}$ tabel pada taraf signifikansi $90 \%$ maka $\mathrm{HO}$ ditolak dan $\mathrm{H} 1$ diterima, yang artinya terdapat hubungan yang signifikan antara luas lahan dengan persepsi petani terhadap UPJA. Hal ini menunjukkan bahwa perbedaan luas lahan petani yang diusahakan untuk usahatani berhubungan dengan persepsi petani terhadap UPJA. Hubungan yang signifikan antara luas lahan petani dengan persepsi petani terhadap UPJA menunjukkan bahwa persepsi petani berhubungan dengan luas lahan, sehingga sempit atau luasnya lahan petani berhubungan dengan baik ataupun buruk persepsi petani terhadap UPJA. Hasil penelitian ini sesuai pernyataan Lionberger dalam Mardikanto (1993) bahwa luas yang diusahakan juga dapat berpengaruh karena biasanya semakin luas lahan yang dimiliki maka semakin cepat seseorang mengadopsi. Hal ini disebabkan karena memiliki kemampuan ekonomi lebih baik.

Luas lahan petani responden di Kecamatan Tawangsari dalam kategori sangat luas yaitu mayoritas petani responden memiliki luas lahan antara 1,10-1,32 Ha. Semakin luas lahan yang dimiliki maka petani responden semakin membutuhkan alsintan untuk membantu usahataninya. Maka semakin cepat pula petani mengadopsi inovasi pemanfaatan kelembagaan UPJA. Petani 


\section{Husnayati, Suwarto, Ihsaniyati, Faktor Pembentuk,נ,}

responden yang memiliki lahan sawah yang luas maka semakin banyak pula tenaga pertanian yang dibutuhkan dalam usahataninya. Namun, kaitannya dengan ketersediaan tenaga pertanian yang semakin berkurang maka dengan adanya kelembagaan UPJA, masalah yang dihadapi petani responden tersebut dapat diatasi. Semakin sering petani mengadopsi inovasi kelembagaan UPJA menunjukkan bahwa semakin baik pula persepsi petani terhadap UPJA.

Hubungan antara lingkungan ekonomi dengan persepsi petani terhadap UPJA

Berdasarkan Tabel 3 dapat diketahui bahwa nilai koefisien korelasi ( $r s$ ) sebesar $0.486^{* *}, \mathrm{p}$ value sebesar 0,000 , dengan $t$ hitung sebesar 4,235 dan $t$ tabel sebesar 2,680 sehingga dapat diketahui bahwa $\mathrm{t}$ hitung $>\mathrm{t}$ tabel pada taraf signifikansi $99 \%$ maka $\mathrm{HO}$ ditolak dan H1 diterima, yang artinya terdapat hubungan yang signifikan antara lingkungan ekonomi dengan persepsi petani terhadap UPJA. Hal ini menunjukkan bahwa perbedaan lingkungan ekonomi petani berhubungan dengan persepsi petani terhadap UPJA. Hubungan yang sangat signifikan antara lingkungan ekonomi petani dengan persepsi petani terhadap UPJA menunjukkan bahwa persepsi petani sangat berhubungan dengan lingkungan ekonomi.

Hubungan yang signifikan antara lingkungan ekonomi dengan persepsi petani terhadap UPJA tidak terlepas dari faktor ekonomi. Keuntungan yang akan didapatkan oleh petani akan mempengaruhi petani dalam memanfaatkan jasa dari UPJA. Apabila keuntungan yang didapat lebih besar apabila tidak memanfaatkan UPJA maka kemungkinan petani yang memanfaatkan UPJA akan berkurang begitu pula sebaliknya apabila keuntungan yang didapat apabila memanfaatkan UPJA lebih tinggi maka persepsi petani terhadap UPJA akan baik pula.

\section{Perbedaan Persepsi Petani Terhadap UPJA}

Tabel 4 Hasil Analisis Uji Beda

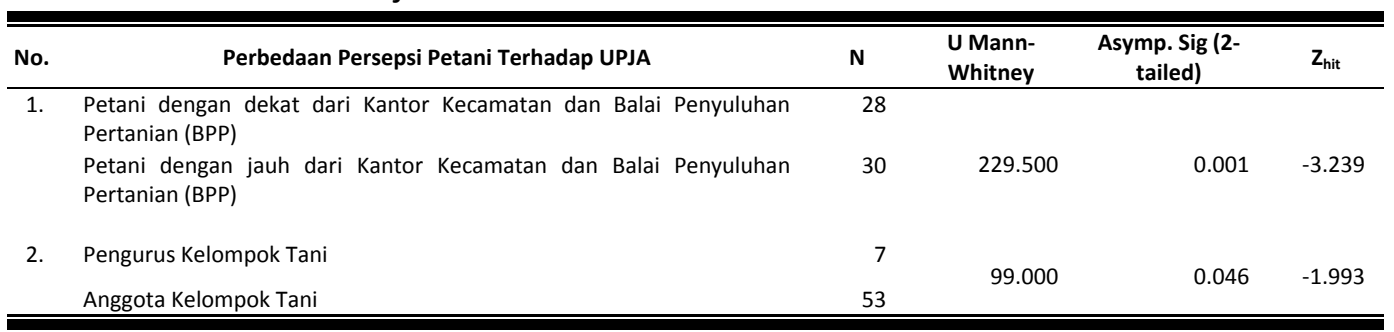

Sumber: Analisis Data Primer Tahun 2017

Keterangan: $\alpha: 0,05 \quad Z_{\text {hit }}: Z$ hitung $\quad Z_{\text {tabel }}: 1,96(\alpha: 0,05)$ 
Jurnal Agritexts Volume 42 Nomer 1 Mei 2018

Perbedaan persepsi petani terhadap UPJA (Usaha Pelayanan Jasa Alsintan) berdasarkan lingkungan petani (petani yang jarak akses dekat dari Kantor Kecamatan dan Balai Penyuluhan Pertanian (BPP) dengan petani yang jarak akses jauh dari Kantor Kecamatan dan Balai Penyuluhan Pertanian (BPP)

Berdasarkan Tabel 4 menunjukkan bahwa nilai Mann-Whitney sebesar 229,500 dan Asymp. Sig. sebesar 0,001 serta $Z_{\text {hit }}$ sebesar 3,239. Maka $Z_{\text {hit }}>Z_{\text {tabel }}$ yaitu -3,239 > 1,96, sehingga $H_{0}$ ditolak dan $H_{1}$ diterima. Artinya terdapat perbedaan persepsi yang signifikan terhadap UPJA berdasarkan lingkungan petani yaitu antara petani yang jarak akses dekat dari Kantor Kecamatan dan Balai Penyuluhan Pertanian (BPP) dengan petani yang jarak akses jauh dari Kantor Kecamatan dan Balai Penyuluhan Pertanian (BPP).

Perbedaan persepsi ini menunjukkan bahwa petani dalam menilai obyek akan bergantung pada intensitas informasi yang didapat. Petani yang jaraknya dekat dengan akses informasi cenderung lebih aktif terhadap inovasi baru, artinya informasi yang didapat petani yang jaraknya dekat dengan akses informasi cenderung lebih banyak dibandingkan petani yang jaraknya jauh dengan akses informasi. Petani yang jaraknya dekat dengan akses informasi akan lebih mudah memanfaatkan fasilitas yang ada dibandingkan dengan petani yang jaraknya jauh dengan akses informasi, sehingga dalam mencari dan memperoleh informasi terkait inovasi baru akan lebih cepat dan mudah.

Perbedaan persepsi petani terhadap UPJA (Usaha Pelayanan Jasa Alsintan) berdasarkan kedudukan petani pada kelompok tani (Pengurus dan Anggota kelompok Tani)

Berdasarkan Tabel 4 menunjukkan bahwa nilai Mann-Whitney sebesar 99,000 dan Asymp. Sig. sebesar 0,046 serta $Z_{\text {hit }}$ sebesar 1,993. Maka $Z_{\text {hit }}>Z_{\text {tabel }}$ yaitu $-1,993$ $>1,96$, sehingga $H_{0}$ ditolak dan $H_{1}$ diterima. Artinya terdapat perbedaan persepsi yang signifikan terhadap UPJA berdasarkan kedudukan petani pada kelompok tani yaitu antara pengurus dengan anggota.

Perbedaan persepsi antara pengurus kelompok tani dengan anggota kelompok tani merupakan salah satu implikasi dari keaktifan petani dalam mencari dan memperoleh informasi terkait suatu inovasi baru atau program pertanian. Pengurus kelompok tani cenderung lebih aktif dalam mencari informasi, diantaranya dengan melalui kegiatan-kegiatan yang dilakukan seperti pertemuan rutin kelompok tani dan perwakilan kelompok tani dalam sosialisasi dan pelatihan yang dilakukan oleh dinas atau instansi 
terkait seperti Dinas Pertanian dan Balai Penyuluhan Pertanian. Pengurus kelompok tani biasanya lebih aktif dalam kehadiran di pertemuan kelompok tani, di samping itu pula pengurus cenderung lebih banyak mengikuti kegiatan pendidikan non formal, meliputi penyuluhan, pelatihan dan kunjungan, sehingga lebih banyak informasi yang didapat yang akan dijadikani bahan pertimbangan petani dalam setiap pengambilan keputusan terkait suatu inovasi baru maupun program pemerintah, baik dari pemerintah pusat maupun pemerintah daerah.

\section{KESIMPULAN DAN SARAN}

Berdasarkan hasil penelitian dan pembahasan yang mengkaji persepsi petani terhadap UPJA (Usaha Pelayanan Jasa Alsintan) di Kecamatan Tawangsari Kabupaten Sukoharjo, maka dapat ditarik kesimpulan sebagaiberikut:

Faktor-faktor pembentuk persepsi petani terhadap UPJA (Usaha Pelayanan Jasa Alsintan) di Kecamatan Tawangsari Kabupaten Sukoh arjo yaitu umur responden termasuk dalam kategori sedang, pendidikan formal responden termasuk dalam kategori tinggi (SMA), pendidikan non formal termasuk dalam kategori sangat rendah, pengalaman responden termasuk dalam kategori, pendapatan responden termasuk dalam kategori sangat tinggi, luas lahan responden termasuk dalam kategori sangat dan lingkungan ekonomi responden berada dalam kategori sedang.

Persepsi petani terhadap UPJA (Usaha Pelayanan Jasa Alsintan) di Kecamatan Tawangsari Kabupaten Sukoharjo termasuk dalam kategori baik pada persepsi petani terhadap pengertian UPJA, manfaat UPJA dan kegiatan UPJA.

Hubungan antara faktor-faktor pembentuk persepsi dengan persepsi petani terhadap Usaha Pelayanan Jasa Alsintan) di Kecamatan Tawangsari Kabupaten Sukoharjo. Terdapat hubungan yang sangat signifikan antara pendidikan non formal dan lingkungan ekonomi dengan persepsi petani terhadap UPJA pada taraf kepercayaan sebesar 99\%; faktor pengalaman, pendapatan, dan luas lahan terdapat hubungan yang signifikan dengan persepsi petani terhadap UPJA dengan taraf kepercayaan $90 \%$; sedangkan untuk faktor umur dan pendidikan formal tidak terdapat hubungan yang signifikan dengan persepsi petani terhadap UPJA.

Terdapat perbedaan persepsi yang signifikan terhadap UPJA berdasarkan lingkungan petani yaitu antara petani yang jarak akses dekat dari Kantor Kecamatan dan Balai Penyuluhan Pertanian (BPP) dengan petani yang jarak akses jauh dari Kantor Kecamatan dan BPP serta 


\section{Jurnal Agritexts Volume 42 Nomer 1 Mei 2018}

terdapat perbedaan persepsi yang signifikan terhadap UPJA berdasarkan kedudukan petani pada kelompok tani yaitu antara pengurus dengan anggota.

Adapun saran yang dapat di berikan oleh peneliti yaitu: Petani perlu meningkatkan keaktifan dalam mengikuti kegiatan-kegiatan baik yang terkait UPJA maupun kegiatan terkait kegiatan lain yang berkaitan di bidang pertanian, melalui sosialisasi, pelatihan maupun kegiatan lainnya sehingga dapat meningkatkan wawasan dan pengetahuan petani

Bagi Penyuluh Pertanian Lapang (PPL) Kecamatan Tawangsari, perlu meningkatkan keaktifannya dalam memberikan informasi terkait UPJA kepada semua petani di Desa Majasto sehinggga petani dapat mengetahui dan memahami dengan baik terkait UPJA dan dapat memanfaatkan keberadaan UPJA dengan baik.

Dinas Pertanian perlu memperluas wilayah sasaran dan meninjau kembali bantuan alsintan yang dibutuhkan oleh petani dan yang sesuai dengan kondisi lapang sehingga bantuan alsintan tersebut dapat digunakan dengan baik oleh petani.
Perbedaan persepsi antara petani yang jauh dari akses Kantor Kecamatan dan BPP dengan petani yang dekat dari akses Kantor Kecamatan dan BPP perlu adanya kegiatan sosialisasi maupun pelatihan terkait UPJA dan fasilitas untuk usahatani yang seimbang dan merata sehingga dapat meminimalisir perbedaannya.

\section{DAFTAR PUSTAKA}

As'ad, Moh. 1995. Psikologi Industri: Seri Ilmu sumber Daya Manusia. Liberty. Yogyakarta.

Hernanto, Fadholi. 1984. Petani Kecil, Potensi dan Tantangan Pembangunan. Ganesha. Bandung.

Kementerian Pertanian. 2008. Lampiran Peraturan Mentri Pertanian No. 25/2008. Tentang Penumbuhan dan Pengembangan UPJA dan Mesin Pertanian.

Mardikanto, T. 1993. Penyuluhan Pembangunan Pertanian. UNS Press. Surakarta

Mulyana, D. 2002. IImu Komunikasi Suatu Pengantar. PT. Remaja Rosdakarya. Bandung. 2005. IImu Komunikasi Suatu Pengantar. PT. Remaja Rosdakarya. Bandung.

Rakhmat, J. 2003. Psikologi Komunikasi. PT Remaja Rosdakarya. Bandung. 
Husnayati, Suwarto, Ihsaniyati, Faktor Pembentuk,,

-2005. Psikologi Komunikasi, edisi revisi. PT Remaja Rosdakarya. Bandung.

Singarimbun, Masri dan Sofian, Effendi. 1989. Metode Penelitian Survey. PT. Pustaka LP3ES. Jakarta

Soekartawi. 1988. Prinsip Dasar Komunikasi Pertanian. UI Press. Jakarta. 